\title{
HANS KELSEN: A PEACEMAKER THROUGH LAW
}

\section{Mario Patrono*}

Mario Patrono has made many visits to New Zealand, and to Victoria University of Wellington School of Law in particular, during the course of his career. Most recently he has been a Visiting Professor at the Law School, arriving for the first trimester of 2013, 2014, and soon 2015, enjoying Wellington's calmer autumn months, then sensibly returning to Rome before winter takes hold. During each of these visits Professor Patrono leads a seminar class on the fundamentals of European Union law for honours and masters students. He also contributes to the intellectual life of the Law School more generally, speaking at staff and student events. This article is based on one of those speaking engagements.

The context of this talk was a Law School student seminar on the history and theory of international law led by Dr Guy Sinclair. Professor Patrono was invited to introduce the students to the work of Hans Kelsen. In this lecture he outlines Kelsen's background and key works for this audience, touching on subjects such as Kelsen's departure from Europe and early reception in the United States, before challenging those present with the notion that Kelsen's work might have something to offer New Zealand constitutional scholarship.

In Geneva, Kelsen had noticed a former student in the classroom. Desirous of saying a few kind words to him but having forgotten his name, he apologized: "Please forgive me that I have not called you by your name. I have a very bad memory for names and often fear that when awakening one morning I may not be able to remember my own." The young man, a Frenchman, bowed and replied: "Mon cher Maître, perhaps you may not be able to recall your name, but world history will never forget it."1

1. Hans Kelsen is not an antique. He is not someone we talk about in relation to facts or theories belonging to the past, more or less distant from today, as we do in regard to Napoleon at Waterloo. That Kelsen's work can, of course, also be seen in a historic perspective has been shown recently by Tamara Ehs. Ehs has analysed and compared Felix Frankfurter's and Hans Kelsen's

* Professor of Public Law, University of Rome I; regular visitor to Victoria University of Wellington Law School.

1 Albert A Ehrenzweig "Preface: A Tribute to Hans Kelsen" (1971) 59 Cal L Rev 609 at 611. 
ideas on the political and legal aspect of constitutional jurisprudence and its compatibility with the democratic principle of majority rule in her article, "Felix Frankfurter, Hans Kelsen, and the Practice of Judicial Review". ${ }^{2}$ I myself also did so, studying the contribution to the construction of his Reine Rechtslehre (the Pure Theory of Law) ${ }^{3}$ given by one of Kelsen's greatest disciples, namely Adolf Merkl. $^{4}$

Kelsen is a scholar who has influenced as perhaps no other contemporary legal thought. His influence on great philosophers of law like Alf Ross, HLA Hart, Joseph Raz, John Rawls and, at least by contrast, philosophers of law like Julius Stone and Ronald Dworkin, who were all prominent scholars very well known inside the common law countries, is indisputable (HLA Hart calls Kelsen "the most stimulating writer on analytical jurisprudence of our day"). ${ }^{5}$

Most importantly, Kelsen has directly or indirectly impacted on the construction and the working of states' legal orders. Furthermore, his influence is still acutely apparent in the way that the international legal order has developed. In fact, this is the only - the real reason - that explains why so many books and articles still continue to study Kelsen as a general theorist of law or as a scholar of international law, each time "revisiting" or "reinterpreting" him. This is evidenced, more recently by Kelsen Revisited, New Essays on the Pure Theory of Law. ${ }^{6}$

The task before me is to explain in a few words, who Kelsen is today. To this end, my lecture will revolve around two dates: 21 June 1940 and 26 April 1952.

2. On 21 June 1940, Hans Kelsen arrives in New York, on the "SS Washington". Two questions immediately arise:

A) Who was Kelsen to the American community of legal scholars, at the moment of his arrival? Certainly he was not an unknown. At that time Kelsen was very well known to internationalists around the world, including both Americans and foreign scholars who had settled in America. Phillip C Jessup knew him very well, as did Edwin Borchard, Charles G Fenwick, Manley O

2 Tamara Ehs "Felix Frankfurter, Hans Kelsen and the practice of Judicial Review" [2013] Zeitschrift für ausländisches öffentliches Recht und Völkerrecht 451.

3 See Hans Kelsen Pure Theory of Law (translation from $2 \mathrm{~d}$ rev and enl German ed by Max Knight, University of California Press, Berkeley, 1967).

4 Mario Patrono Hans Kelsen, Storia di tre Storie/Hans Kelsen, The Story of Three Stories (Giuffre Editore, Milano, 2000).

5 HLA Hart "Kelsen Visited" (1963) 10 UCLA L Rev 709 at 728. See also Andrew Halpin "Austin's Methodology? His Bequest to Jurisprudence" (2011) 70 CLJ 175 at 178 and n 10.

6 Luís Duarte d'Almeida, John Gardner and Leslie Green (eds) Kelsen Revisited: New Essays on the Pure Theory of Law (Hart Publishing, Oxford, 2013). 
Hudson, and Quincy Wright. Obviously Hersh Lauterpacht knew Kelsen very well and indeed Kelsen was known - maybe better than everyone else - by Josef L Kunz, his disciple at Vienna, who taught in the United States from 1935.

Kelsen, in particular, was very well known by those who praised or opposed his four key theories concerning international law:

- The monism on the relation between domestic and international law. According to Kelsen, monism means the unity of national and international law as part of the same system of norms receiving its validity from a "basic norm". This unity comes, in Kelsen's thought, from the concept of "collision of duties". The same individual cannot be bound by two duties at the same time that work as two opposite forces. He or she cannot obey at the same time, national and international law. The unity of national and international law, therefore, is a postulate of legal theory. Primacy of national law, or primacy of international law, in such a unity, cannot be decided by the science of law. This is a political choice, but very important. Kelsen explains: ${ }^{7}$

In our choice, we are obviously guided by ethical and political preferences. A person whose political attitude is one of nationalism and imperialism will naturally be inclined to accept the hypothesis of the primacy of national law. A person whose sympathies are for internationalism and pacifism will be inclined to accept the hypothesis of the primacy of international law. From the point of view of the science of law, it is irrelevant which hypothesis one chooses. But from the point of view of political ideology the choice is important since tied up with the idea of sovereignty.

- The sovereignty. According to Kelsen, the state's "sovereignty" is not a brute and unbridled power. It is not a political decision that comes from outside the law. By contrast, Kelsen totally reabsorbs the "sovereignty" into the realm of the law. Indeed, for Kelsen, the "state" is nothing more than a set of rules, offices, competences and procedures. Thus, according to Kelsen, the sovereignty becomes an attribute of the state as the supreme legal order, that is, the sole legal order that doesn't derive its validity from a superior legal order, but enjoys its own independent validity. Moreover, the same concept of the state as the supreme legal order can be questioned. If we admit the supremacy of international law over domestic law, the "sovereignty" would fade because the state, in Kelsen's view, would become a mere organ of the international legal community.

7 Hans Kelsen General Theory of Law and State (translated by Anders Wedberg, Harvard University Press, Cambridge (Mass), 1946) at 388. On Kelsen's idea of "unity of law", see HLA Hart "Kelsen's Doctrine of the Unity of Law" and Ronald Dworkin "Comments on the Unity of Law Doctrine (A Response)" in Howard E Keifer and Milton K Munitz (eds) Ethics and Social Justice (State University of New York Press, Albany, 1970) 171 and 200. See also Stephen Munzer "Validity and Legal Conflicts" (1973) 82 Yale LJ 1140 . 
All this means, in a few words, is that the "power" is forced to stay within the tracks of law. In fact, there was a time when the states did not feel bound and were not bound to follow the law, as examined by Kelsen at that time. The world has thankfully changed along the lines foreseen so early by Kelsen. Now, the more that totalitarian regimes are brutal and ruthless the more they love to act in the cover of darkness. When the spotlight of information comes onto them, the conflict between their behaviour and their own rules becomes evident. The same thing, but in a smaller number of cases, can be repeated in regard to democracies, where states are able to hide behind the Raison d'État. We could think here, for example, of Guantanamo Bay.

- $\quad$ The concept of "just" war. Until the immediate eve of the First World War (1914) and ab immemorabili, war was accepted as a right of any state: that was exercised as self-help to enforce a "right" (largely speaking), or as a way to change the existing law (see on that, Josef L Kunz "Bellum Justum and Bellum Legale"). ${ }^{8}$

From the same year (1914), Kelsen maintained a completely different opinion although this was initially at an embryonic stage ("Reichsgesetz und Landesgesetz nach österreichischer Verfassung", ${ }^{9}$ and then further developed in Das Problem der Souveränität und die Theorie des Völkerrechts, Beitrag zu einer reinen Rechtslehre, dating back to the First World War but published in 1920). ${ }^{10}$ War, wrote Kelsen, is a legal phenomenon belonging to the sphere of international law: "A war other than a war required (or clearly admitted) by the international law must be considered, from the legal point of view, just as an act of force, an offence (Unrecht), a violation of international law." ${ }^{11}$ If war cannot be interpreted either as a crime or as a sanction against a crime, then it is no longer possible to consider international law as law at all. It is significant here that Kelsen fiercely rejected the idea, supported by many scholars until the Second World War and maybe beyond, that war, alongside its function of enforcing the (international) law, would also be an equally lawful way for one or more states to seek to change the existing law. Kelsen rejected, in particular, the idea that war can play in the field of general international law the same role that revolution plays in the field of national law. ${ }^{12}$ We can agree with Kelsen about his conclusion (that war cannot be a lawful means of revolutionary change of law), but not about his explanation. It is not true (except in a purely formal sense) that war - as Kelsen

8 Josef L Kunz "Bellum Justum and Bellum Legale" (1951) 45 Am J Int'l L 528.

9 Hans Kelsen "Reichsgesetz und Landesgesetz nach österreichischer Verfassung" (1914) 32 AoR 202.

10 Hans Kelsen Das Problem der Souveränität und die Theorie des Völkerrechts. Beitrag zu einer reinen Rechtslehre (1920) (2nd ed, JCB Mohr, Tübingen, 1928).

11 Kelsen, above n 10, at 265.

12 Hans Kelsen "Théorie du Droit International Public (1953, III) 84 Recuil de Cours 44. 
assumes - does not produce changes in international law. On the contrary, it is a statement of fact that war, any war, produces - through consequential international agreements changes of international law, whether large or small: which are planned by a state (or group of states) that sparked the war, or planned by the state (or group of states) which responded to the war with war, and won. This means that, by accepting the idea of war as a way to produce a revolutionary change in the law, any war would be lawful. So, we would have a situation between states of absolute barbarism. The conclusion, although reached by another road, is once again that, if war cannot be interpreted either as a crime or as a sanction against a crime, then it is no longer possible to consider international law as law at all. Regardless, it would take 30 years and two World Wars before Kelsen's idea of jus bellum as war in accordance with the law (rechtmäßiger Krieg, in German) would be established at the level of positive international law. Finally in 1945 the Charter of the United Nations transformed the "jus belli" into "jus contra bellum" (the "right to war" into the "law against the war"), and affirmed the principle that the use of armed force as a sanction is a lawful monopoly of the international community. ${ }^{13}$

- A compulsory jurisdiction at the level of international law. From $1934,{ }^{14}$ Kelsen insisted that an international tribunal, rather than an international executive or legislature, should be the prime instrument for maintaining peace within the international community.

This idea of building world peace around a court with compulsory jurisdiction, that Kelsen shared with Hersch Lauterpacht, his old student at the Law School of the University of Vienna (for more, see Hans Kelsen, "Tributes to Sir Hersch Lauterpacht") ${ }^{15}$ has not been adopted in the Charter of the United Nations - I will return to this shortly.

3. Kelsen was much less known, although not entirely unknown, by American scholars of other fields of law. There were three sources of information on Kelsen before his arrival in the United States: (a) some of Kelsen's writings translated into English, including a synthesis of Pure Theory of Law; ${ }^{16}$ (b) some writings on Kelsen published in leading law periodicals; ${ }^{17}$ and (c) Kelsen's representation by the American great philosopher of law, Roscoe Pound. He wrote that: ${ }^{18}$

13 See, in a logical order, arts 2(2), 51, 39, 41, 42, 2(7) of the Charter of the United Nations.

14 Hans Kelsen The Legal Process and International Order (New Commonwealth, London, 1934).

15 Hans Kelsen "Tributes to Sir Hersch Lauterpacht" (1961) 10 ICLQ 196; reprinted in (1997) 8 EJIL 309 at 309-310.

16 See for example Kelsen, above n 14; Hans Kelsen "The Pure Theory of Law, its Method and Fundamental Concepts" (1934) 50 LQR 474; (1935) 51 LQR 517; Hans Kelsen "The Party Dictatorship" (1936) 2 Politica 19; Hans Kelsen "The Soul and the Law" (1937) 1 Review of Religion 357; Hans Kelsen "The Philosophy of Aristotle and the Hellenic-Macedonian Policy" (1937) 48 Ethics 1; Hans Kelsen "The 
Kelsen $\ldots$ is unquestionably the leading jurist of the time. His disciples are devoted and full of enthusiasm in every land. His ideas are discussed in all languages. His followers are probably the most active group in contemporary jurisprudence.

A similar judgement would be repeated by Julius Stone many years later, on the occasion of Kelsen's 90th birthday, in his "Message" in which, however, the envy shines clear: ${ }^{19}$

Less than a year ago, under the rubric "Philosophy of Law" of the forthcoming Encyclopaedia

Britannica, I wrote these words: "Roscoe Pound assessed Hans Kelsen in 1934 as 'unquestionably the

leading jurist of his time', an assessment which it is a singular pleasure to reaffirm in 1970, as Kelsen's

90th birthday approaches at this time of writing".

Last but not least, we must note that in 1936 the Harvard School of Law awarded Kelsen an honorary doctorate on the occasion of that University's Tercentenary.

More than unknown, therefore, Kelsen in 1940 was a kind of alien in the United States, that is, a lawyer who came from a world of law so entirely foreign to the world of the common law. He was a lawyer whose neo-Kantian normative logicism, whose formalism, seemed to be totally incomprehensible to American scholars of law who were (and are) so connected to the living experience of the law and justice of each judicial case, and who have been accustomed to receiving by those who are engaged in the practice of law the so familiar admonition: "Give us something we can use". In particular, they found it extremely difficult to comprehend:

- Kelsen's theory according to which wrong is not negation but condition of the law. The legal norm (as opposed to the moral norm) has a conditional structure: if A behaves in a way prohibited by law or doesn't behave in a way that the law prescribes as compulsory, then B, authorised by the legal order to do so, must apply the sanction: which is shaped most of the time as punishment, or far more rarely, as a reward. It follows from this that the first, the true addressee of the norms established by the law, is the one who, acting as an

Function of the Pure Theory of Law" in Alison Reppy (ed) Law, a century of progress, 1835-1935 (New York University Press, New York, 1936) vol 2 195; Hans Kelsen "Platonic Justice" (1937) 48 Ethics 367; and Hans Kelsen "The Separation of the Covenant of the League of Nations from the Peace Treaties" in World Crisis (Graduate Institute of International Studies, London, 1938) 133.

17 See for example I Husik "The Legal Philosophy of Hans Kelsen" (1938) 3 Journal of Scientific Philosophy 297; Henry Janzen "Kelsen's Theory of Law" (1937) 31 American Political Science Review 205; Josef L Kunz "The 'Vienna School' and International Law" (1934) 11 NYU LQ Rev 370; Roscoe Pound "Fifty Years of Jurisprudence" (1938) 51 HLR 449; WB Stern "Kelsen's Theory of International Law" (1936) 30 American Political Science Review 736; Erich Voegelin "Kelsen's Pure Theory of Law" (1927) 42 Political Science Quarterly 268; and Charles H Wilson "The Basis of Kelsen's Theory of Law" [1934] Politica 54.

18 Roscoe Pound "Law and Science of Law in Recent Theories" (1934) 43 YLJ 525 at 532.

19 Julius Stone "Message From Julius Stone" (1971) 59 Cal L Rev 612 at 612. 
organ of the community, will have to apply the sanction in response to a legally wrong behaviour.

- Kelsen's theory holds that coercion is the distinctiveness of the law, that is, a view of law centred on the theory of operant conditioning - the idea that behaviour is shaped by negative "reinforcement" from punishment and positive "reinforcement" from reward. This is a view of law that seems, or better, seemed to contrast especially with the reality of international law and so was also hard to digest.

- The American scholars were especially frustrated with dealing with the concept of "basic norm" (the "Grundnorm", in German), finding it a bit mystical. Kelsen defines the Grundnorm as a norm beyond the positive law, a norm postulate. From it depends, in Kelsen's view, the validity of the whole system of norms, that is, the entire legal order. This concept is not as difficult to understand as one might think. The initial question is: why do I obey the parking warden in paying a fine that he applies to me, for example, of $\$ 50 \mathrm{New}$ Zealand dollars as I had parked my car in a "no parking" zone, while I refuse to hand over $\$ 50$ New Zealand dollars, to someone who tried to rob me? The answer is: I hand over the sum of money to the parking warden because he exercises a power that comes from an order of the City Council, and because he has been recruited following the procedures established by an order of the City Council. But why does the City Council have the power to set the rules for the recruitment of local parking wardens and give them a number of powers? Because an Act of Parliament authorises the City Council to do so. But from where does the Parliament derive its power to authorise the City Council to exercise certain powers within a defined territorial area? And the questions going back may continue to a point $\mathrm{X}$ that is above the constitution, whether written or unwritten. At that point $\mathrm{X}$, the answers may be various. The utilitarian theory - derived from Hobbes - says: I obey the law because the state, in exchange for a substantial part of my freedom, protects me from murderers and thieves. The theory of natural law says: I obey the law because the power of the rulers comes from God (Saint Paul) or I obey only in so far as the law is just (St Augustine). Kelsen says: I obey the law because at the top of the pyramid of norms (of which the parking warden of our example is on the lower level), there is the Grundnorm. Kelsen presents the "basic norm" as a metaphysical norm. In my view, the "basic norm" is nothing more than the general idea that those who are in power have the legal authority to rule, that is, it coincides with the "efficacy" of the legal order as a whole. ${ }^{20}$

It has to be noted that Kelsen continued to focus on the general theory of law in the United States, thus confirming the conviction of the American scholarship that he was not much more than an abstract logician. For example, Kelsen - following here an old suggestion that comes from Adolf

20 See on that, the very easy explanation given by Kelsen: Hans Kelsen "On the Basic Norm" (1959) 47 Cal L Rev 107. 
Merkl $^{21}$ - does not hesitate to explain to a stunned audience of American scholars his view about the repeal of the validity of a norm by another norm. In Kelsen's thought, the principle that the later law prevails (repealing or derogating) the previous law - that is the principle of lex posterior derogat priori - is not at all more logical then the opposite principle according to which the previous law prevails on the next. If therefore the subsequent law prevails over the previous one, that cannot happen except by the effect of the positive law which may determine this prevalence explicitly - as happens, but rarely - or implicitly. It must therefore admit - in the absence of an explicit provision - that every law encapsulates an implied clause (as a norm pertaining to positive law) which determines its own extinction at occurrence of the next incompatible law. I would define such a clause as an implied "suicide clause". ${ }^{22}$ Kelsen further elaborates on this view in his General Theory of Norms, published posthumously by Oxford University Press in $1991 .^{23}$

4. In reality, the American scholars looked at Kelsen one dimensionally and thus they had a distorted perception of his thought. They were deprived of a full understanding of Kelsen. Kelsen was much more than someone who simply applied formal logic to the law.

Of course, Kelsen was a formidable tightrope of logic and he rested many of his analyses on logic, rather than experience. In 1948, for example, on the basis of purely logical consideration, he came to explain that the Soviet Union - which was at that moment at the height of its military strength and which had control of half of the world - would inevitably implode due to a lethal mixture of despotism, bureaucracy and lack of motivation of people to work. ${ }^{24}$

To repeat, when Kelsen arrived in New York in 1940, he was held in far lower esteem by the American legal scholars than was justified.

Kelsen, more than 20 years earlier, had invented (I repeat: "invented", not simply "disclosed") the technical mechanism by which it has been possible that judicial review on legislation established by Chief Justice John Marshall in Marbury $v$ Madison ${ }^{25}$ - can work even in countries where the rule of precedent is not in force: I mean the Constitutional Court.

21 Adolf Merkyl Allgemeines Verwaltungsrecht (Julius Springer, Wien und Berlin, 1927) at 211

22 Hans Kelsen "Derogation" in Ralph A Newmann (ed) Essays in Jurisprudence in Honour of Roscoe Pound (Bobbs-Merrill, Indianapolis, 1962) 339 at 355.

23 Hans Kelsen General Theory of Norms (Oxford University Press, Oxford, 1991) at [27].

24 Hans Kelsen The Political Theory of Bolshevism: A Critical Analysis (University of California Press, Berkeley, 1948).

25 Marbury v Madison 5 US (Cranch 1) 137 (1803). 
In doing so, Kelsen achieved two main goals: First, to transform the Constitution of many countries from simple political programme into "law" in the technical sense of the word: the Higher Law of the Land. This extended into continental Europe around 1919, the first seed of the principle of limited government through the jurisdiction (the principle of modern constitutionalism) up to the top level: the Acts of Parliament. Secondly, as a result of a new Constitutional Court, a significant part of political issues become legal issues. Kelsen has interpreted this transposition of the political process into law as pacification, highlighting the conciliatory function of law.

Here, before we go forward, I must just mention the controversy which contrasted harshly Kelsen and Carl Schmitt around the issue of what was the most appropriate organ of the state to exercise control on legislation. Against Schmitt, who saw in the court proceedings a telum imbelle sine actu and reposed in the extraordinary powers of the president elected by the people the true guarantee of the constitution (according to the famous art 48 of the Weimar Constitution), ${ }^{26}$ Kelsen maintains that such a plebiscitary consent envisaged by Schmitt openly contrasts with the physiological mechanism of the democratic process, while it is consistent with the dialectic that occurs in the courts. ${ }^{27}$

Controversy has dogged the field ever since then, as well as before, starting from Marbury. ${ }^{28}$ Because the judicial review mechanism involves democratic majority rule and freedom of choice by representative government, its political dimension has been fiercely debated but the search for alternatives is not going well. In France, for example, the process of controlling legislation, entrusted to a political body (the Constitutional Council), is becoming increasingly similar to the structure of judicial review.

Anyway, the idea of the Constitutional Court spread quickly, first in Czechoslovakia and then in Spain. Following abolition of the existing Constitutional Courts by Nazis and the Franco regime, which did not allow checks on the exercise of power, the idea of a Constitutional Court received after the Second World War a growing success all over the civil law countries, European and beyond, together with the adoption of written and entrenched constitutions. ${ }^{29}$

$$
* * *
$$

26 Carl Schmitt "Der Hüter der Verfassung” 1929 AoR 161.

27 Hans Kelsen "Wer Soll der Hüter der Verfassung Sein? [1931] Die Justiz 6.

28 See on that James M O'Fallon "Marbury" (1992) 44 SLR 219.

29 See Mark Tushnet "Judicial Review of Legislation" in Mark Tushnet and Peter Cane (eds) The Oxford Handbook of Legal Studies (Oxford University Press, Oxford, 2003) 164 at 166 onwards; and Tom Ginsberg "The Global Spread of Constitutional Review" in KE Whittington, RD Keleman and GA Caldeira Oxford Handbook of Law and Politics (Oxford University Press, Oxford, 2008) 81. 
5. B) Why had Kelsen left Europe, accepting the invitation by Roscoe Pound and Felix Frankfurter to teach at Harvard Law School? Because Kelsen was doubly hunted in Europe: as Jewish (and Carl Schmitt insulted him, calling him "dirty Jew"), and as Kelsen.

Totalitarian regimes, perhaps better than democracies, know how to identify their enemies; and Kelsen, as the first exponent of the Pure Theory of Law, was for the Nazi regime a dangerous enemy. Hans G Schenk provides proof about this. Schenk, at that time a professor at Wolfson College, Oxford, tells of two episodes to which he was a witness ${ }^{30}$ First episode: In 1936 Kelsen accepted the call from the German University of Prague to take up the chair of Public International Law, wishing to lend his support to the defence of democratic Czechoslovakia, besieged and infiltrated by the Nazis. Kelsen had just started his lecture which in little a time would lead him inexorably and notoriously - to ossify the sovereignty of the state and to relativise it in front of international law, in a broad context of increasing Nazi power and where Germany had recently left the League of Nations. At that point nearly everybody rose and left the hall which had been packed with Nazi students. Those who wished to stay were forcibly removed. Second episode: In 1937 Kelsen gave a talk, in a Prague which was hostage of the Nazis, about the concept of democracy in the light of his Pure Theory of Law. In attendance was a large audience of Czechs, not yet Nazified. Kelsen was applauded at length. These two episodes are - as we can see - highly indicative of the fact that Kelsen was a thorn in the Nazi's flesh.

What "crime", in addition to being Jewish and also beyond any other of his specific theories, had Kelsen committed in the eyes in the Nazi regime? Kelsen was a positivist and as such he separated the law from morality. His "fault" was that he had always stubbornly refused to redeem with the adjective "just" the misdeeds of the detestable Nazi law. Totalitarian regimes need to manipulate the soul, that is, the minds of their subjects. The "legal" obligation to obey the law is not enough, it does not come to consciousness; therefore, one must have the conviction to obey a "just" law. Only in this way will obedience to the law be total. According to Kelsen, however, obedience to the law is certainly an obligation and a value; but together with the "legal" obligation to obey the law there are other obligations and other values. Even obeying one's conscience is an obligation and a value, and the choice in case of conflict between obeying the law and obeying one's own conscience derives from the scale of priorities that each one of us has. So in Kelsen's thought, the conscience is not blurred by the obligation to obey the law; each of us is therefore always free to say no to "this" law that I consider unjust and unacceptable, I do not want to obey (this point was very well explained by Adolf Merkl). ${ }^{31}$

30 Hans Georg Schenk "Hans Kelsen in Prague: A Personal Reminiscence" (1971) 59 Cal L Rev 614.

31 This point was very well explained by Adolf Merkl "Tragödie des Gehorsams" Stuttgarter Zeitung (Germany, 20 January 1950). 
Kelsen's position will be clearer when we better understand the positivism of Kelsen. Here we must make a distinction between "ontological" and "methodological" positivism. An example may be useful. Imagine a pathologist who opens, scans, rummages, and does so for a long time - for hours - with care. Finally, tired and dejected, he gives up and hurriedly sews: the soul that he was looking for inside the corpse has not been found. At this point there are two possible conclusions. First, the soul does not exist ("ontological" positivism: Wittgenstein). Secondly, the soul can exist but it cannot be found with the tool of science ("methodological" positivism: Kelsen).

Moreover, Kelsen was not only unpopular with the Nazis, who confused justice with the unchallenged domination of the Aryan race; Kelsen was also unpopular with Soviet communism, which confused justice with the interests of the proletariat. Vyschinsky, the great theorist of law as well as powerful prosecutor at the time of the purges ordered by Stalin, explains it very well: ${ }^{32}$

[Kelsen's] normativism does not see the material content of social relationships, does not admit the class structure of the society - the struggle of social classes - and does not acknowledge the state as an organ of domination and repression. It excludes all this as metajuridical - lying outside juridical categories and normative ideas.

As we can see, the blame is always the same: Kelsen rejects the idea of the rule through the law, that is, the idea that the scholar of law must be an instrument of power: to support it; to convince subjects to obey the law; to eliminate the political enemies of the regime.

As an aside, in 1948, while Vyschinsky accused Kelsen of not considering the Soviet law as the only valid law, Kelsen explained in detail the reason of the future inevitable collapse of the Soviet Union. History was a good referee between them, showing who was right and who was wrong.

6. 26 April 1952. On that day the American Society of International Law decided to assign to Kelsen the first of its Annual Awards for his book The Law of the United Nations - A Critical Analysis of Its Fundamental Problems, ${ }^{33}$ "as the most distinguished work in the field of international law in the recent years". The motivation for this award is interesting. I read from the 1952 Proceedings of the ASIL: ${ }^{34}$

At the meeting of the Executive Council last Thursday a long and somewhat controversial discussion took place as to the character of the work to which the award might be given. As a result of the

32 Andrei Y Vyshinsky The Law of the Soviet State (Macmillan Co, New York, 1948) at 33.

33 Hans Kelsen The Law of the United Nations: A Critical Analysis of Its Fundamental Problems (Stevens \& Sons Ltd, London, 1950).

34 American Society of International Law Proceedings of the American Society of International Law (1952) at 174. 
discussions, it was definitely understood that the granting of the award did not imply the acceptance by the members of the Society of the particular views of the writer upon a controversial question.

And yet:

Now, it is the opinion of the Committee on Annual Awards, supported by the Executive Council, that the award may be granted to a work which is believed to be one of first-class scholarship without thereby implying any endorsement by the members of the Council itself or of the Society of the point of view of the writer or of the conclusions he reached.

And finally:

It is important to emphasise this, because there was much discussion in the Executive Council about whether it was wise to give the award to a work which appeared to reach conclusions that did not seem to take into account certain practical aspects of the problem, but confined themselves to pure theory.

As we can see, the criticism raised against the idea of giving the award to Kelsen was certainly very heated; just take a look at the reviews of The Law of the United Nations, which appeared in the main legal periodicals in 1950 and 1951, to understand the strength and the content of the criticism: ${ }^{35}$ a masterful display of formalism as applied to the study of the Statute of the United Nations; an exercise of abstract logic. Even an old disciple of Kelsen, Alfred Verdross, had politely accused him of excessive formalism. ${ }^{36}$

7. Yet, in that same year (1952), the process of European integration began which seemed to follow closely the traces marked by Kelsen in his Peace Through Law. ${ }^{37}$ I will explain myself before I move forward. Kelsen was firmly persuaded (between 1942 and 1945 many in American circles were equally convinced), ${ }^{38}$ that the formation of a World State was the best way to achieve a permanent peace between nations: ${ }^{39}$

When the question arises how to secure international peace, how to eliminate the most terrible employment of force, namely, war, from inter-State relations, no answer seems to be more self evident than this: to unite all individual states, or at least, as many as possible, into a World State, to concentrate

35 William Sanders (1951) 39 Cal L Rev 462; Louis B Sohn (1951) HLR 517; Lawrence Preuss (1950) 44 AJIL 792; J Lauterpacht (1950) 27 Br YB Int'l L 498; AH Feller (1951) 51 Colum LR 537; B Cheng (1951) 14 MLR 368; WH Von Rosenstiel (1952) 6 Rutg LR 494; O Schachter (1951) YLJ 189.

36 Alfred Verdross Idées directrices de l' Organisation des Nations Unies (Hague Academy of International Law, Recuil des Cours, 1953).

37 Hans Kelsen Peace Through Law (University of North Carolina Press, Chapel Hill, 1944).

38 See (1944) 38 Am J Int'l L; and (1944) 38 Am J Int'l L Supp 41

39 Kelsen, above n 37, at 4-5, 
all their means of power, their armed forces, and put them at the disposal of a world government under laws created by a world parliament.

Kelsen, however, had clearly in mind (unlike others) that the formation of a World State could be the culmination of a slow and difficult path, but certainly not an immediate conquest.

In Peace Through Law, Kelsen traces the plan of building a futuristic World State. ${ }^{40}$ This plan is anchored to a fundamental premise. Kelsen was convinced that international law - that is, the law of the interstate community completely decentralised and dominated by the principle of self defence would follow the same line of development towards centralisation that the law has followed in the history of human society. This means, more generally, that Kelsen was convinced that from the history of human society it is possible to discover traces capable of indicating future development; and that the track more fruitful in this respect is the law and its history: ${ }^{41}$

The problem of world organisation is a problem of centralisation; and the whole evolution of the law from its primitive beginnings to its standard of today has been, from a technical point of view, a continuous process of centralisation. In the field of municipal law this process is characterised by the surprising fact that the centralisation of the law-applying function - that is, the establishment of courts precedes the centralisation of the law-creating function, the establishment of legislative organs. Long before parliaments as legislative bodies came into existence, courts were established to apply the law to concrete cases. It is a characteristic fact that the meaning of the term 'parliament' originally was a court.

8. The plan traced by Kelsen to build a future World State sets out some essential criteria.

- Gradualism: the establishment of a World Federal State will have to be the result of a long federalising process to be achieved step by step.

- Sectorialism: the creation of a World Parliament and a World Government will be the last steps of the federalising process. Initially, the project must involve a more limited scope and will need to be able to follow the "line of least resistance" to avoid the obstacle placed by nationalism and national sovereignty.

- The first step toward the creation of a World State will have to be the establishment of an international court endowed by compulsory jurisdiction to decide authoritatively so called "political" as well as "legal" disputes between states.

- Supranationality: in the performance of their duties, the judges of the international court shall neither seek nor take instructions from any government or from any other body. Each

40 See for reviews of Peace Through Law: Murray A Gordon (1945) 45 Colum L Rev 667; Grant Gilmore "International Court of Justice" (1946) 55 YLJ 1049 especially at 1060-1061; and Josef L Kunz "Compulsory International Adjudication and Maintenance of Peace" (1944) 38 Am J Int'1 L 673

41 Kelsen, above n 37, at 21. 
Member State undertakes to respect this principle and not to seek to influence the judges of the international court in the performance of their duties.

- Political spill-over: it will require a long process of levelling of crucial differences between the nations of the world. This process, therefore, will have to be supported by a conscious political and educational work in the ideological field.

The criteria indicated by Kelsen in relation to the construction of a future World State, are exactly the same - at a regional level - as are the bases of the integrative process in Europe. ${ }^{42} \mathrm{~A}$ reading of the Schuman Declaration of 9 May 1950, especially the third and fourth paragraphs, and the text of the European Coal and Steel Community (ECSC) Treaty, ${ }^{43}$ illustrates the perfect similarity between the two plans of construction. The reason why this similarity exists - whether or not by chance - is yet to be explained. But the European Union is certainly a political consolidated reality, not an imagination of a logical abstract.

9. I am now in the finishing straight. The Pure Theory of Law has two sides. On the one hand, the Kelsen theory of law is "science" of law. In this sense, The Pure Theory of Law enlightens those which are the formal features of the "law" in its pure state, that is, the "law" decontaminated from any elements external to the "law" such as sociology, ethics, politics and justice. Obviously, Kelsen did not live on the moon. His head was not in the clouds. I would say that in Kelsen's thoughts "law" is an autonomous structure which, however, interacts with politics and with the various social dynamics through various contact points: such as - for example - the interpretation, which usually involves the "choice" (political or moral) by the interpreter between the possible meanings of the legal norm, be it a national or international court, or an individual scholar.

On the other hand, The Pure Theory of Law can be used in order to derive many important democratic options. From the idea of the legal order as a series of processes at various levels hierarchically ordered from a basic norm, Kelsen gave birth to the idea of the Constitutional Court. Again, the "School of Vienna" prepared the draft for the first Austrian law (and the first in Europe) on the administrative procedure, which was - in those days - extremely advanced in the sense that it included the obligatory participation in the procedure of interested people. Another example: when Kelsen operates at the level of politics of law, he chose in favour of the primacy of international law over national law in the sense of internationalism and pacifism. And I could go on.

42 Mario Patrono Diritto dell'Integrazione Europea. Lezioni vol 1: Initium Europae. Storiea delle origini e Fondamenti del Processo Integrativo (CEDAM, Padova, 2013) [The Law of European Integration] at 120145 .

43 Treaty Establishing the European Coal and Steel Community 261 UNTS 140 (signed 18 April 1951, entered into force 23 July 1952). 
10. I conclude. Scientists of nature know very well that they can understand only a small part of the reality that they are studying. They know that, despite the impressive progress of science, there is much to be discovered. The sciences that study nature are a work in progress, a research destined to never end. The same thing applies or should apply to the study of the social world. But here there is a fundamental difference. Those who study society, as opposed to those who study nature, are people usually convinced that they have understood a lot more than they really understand, and think they know the correct treatment for every social ill. Maybe Kelsen belongs to this category of person and maybe his Pure Theory of Law can solve some problems very well, other problems less well and others it cannot solve at all.

In any case I think that a large part of today's international organisations aimed to maintain peace between nations owes much to three great thinkers:

- Adam Smith, who in his seminal work The Wealth of Nations ${ }^{44}$ had proposed a model of integration between states based on freedom of internal as well as international trade. Peace through trade.

- Immanuel Kant, who taught that "republics" are much less prone to war than tyrannical systems: where, having eliminated all the institutions through which public opinion can express its viewpoints and exert pressure on the rulers, there are no longer any obstacles on the exercise of power. Peace through democracy and civil rights.

- Hans Kelsen, who gave the initial decisive push, thanks also to his enormous influence that his works still continue to exercise - towards the so-called "judicialization" of politics both at national and international levels, that is, to get the politics under judicial check that Kelsen interprets as pacification. This phenomenon is now so widespread over the world that it is commonplace. Peace through law.

11. A suggestion for a possible (written and entrenched) New Zealand constitution. Kelsen, not surprisingly, was able to impose with regard to the Austrian Constitution of $1920^{45}$ his idea about a constitution having a purely "procedural" feature, that is, a constitution which should establish only the fundamental organs that will operate at both the federal and state levels, and regulate the powers conferred upon them respectively, as well as the procedures by which the activities of the various institutions provided by the constitution will have to be carried out. A similar constitution, I may add, was the United States Federal Constitution as adopted in Philadelphia in 1787, before being completed by the so called Bill of Rights. The Constitutional Court, in Kelsen's view, should act just as referee which simply ensures that the "players" of politics

44 Adam Smith An Inquiry into the Nature and Causes of the Wealth of Nations (W Strahan and T Cadell, London, 1776) [The Wealth of Nations].

45 Bundesverfassungsgesetz, $1920[B-V G]$. 
obey the rules established for the game by the constitution. So, politics would remain free to reach compromises and pursue values.

This view that Kelsen had about the relationship between the democratic majority rule and judicial review on constitutionality of legislation may perhaps be useful in the light of the current debate on the opportunity (or not) to take up a written and rigid constitution in New Zealand.

In fact, the proposal put forward by Kelsen about the need for the constitution to have a mere "procedural" feature, can provide a threefold advantage. First, it would be able to limit the role of the constitutional court (and the same thing can be said with regard to a court exercising judicial review in the last instance in common law countries) to a referee of the politics/game rules. Secondly, all New Zealanders and the sovereignty of the government representing them could not be disturbed in their function by a judiciary that forcefully enters on it and wants to influence it. Thirdly, future generations would remain free from key choices imposed by those who wrote, maybe 50 or 100 years before, the constitution of the country.

Obviously, a "procedural" constitution - referring to a possible future New Zealand constitution - should be backed by a special judicial body. This could be the Supreme Court of New Zealand having enlarged powers, or (preferably) a new ad hoc court, which checks the compliance by the various branches of government (Parliament, executive, judiciary) with the sphere of competence given to each of them by the constitutional norms, and the fulfilment of the rules of procedure for each of them expressly marked by the constitution. In this context, this special body (the composition of which should be studied very carefully) would exercise judicial review of legislation on very few occasions. 